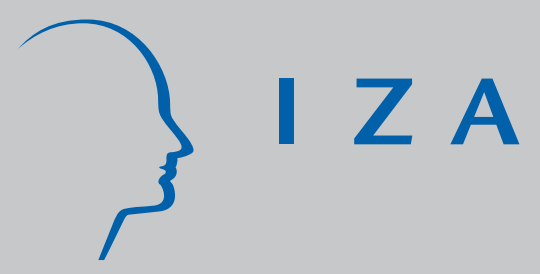

IZA DP No. 2223

Gobalisation, Inequality and Poverty Relationships: A Cross Country Evidence

Marcel Neutel

Almas Heshmati

J uly 2006 


\title{
Globalisation, Inequality and Poverty Relationships: A Cross Country Evidence
}

\author{
Marcel Neutel \\ University of Groningen
}

Almas Heshmati

University of Kurdistan - Hawler, TEPP, Seoul National University and IZA Bonn

Discussion Paper No. 2223

July 2006

IZA

P.O. Box 7240

53072 Bonn

Germany

Phone: +49-228-3894-0

Fax: +49-228-3894-180

Email: iza@iza.org

\begin{abstract}
Any opinions expressed here are those of the author(s) and not those of the institute. Research disseminated by IZA may include views on policy, but the institute itself takes no institutional policy positions.

The Institute for the Study of Labor (IZA) in Bonn is a local and virtual international research center and a place of communication between science, politics and business. IZA is an independent nonprofit company supported by Deutsche Post World Net. The center is associated with the University of Bonn and offers a stimulating research environment through its research networks, research support, and visitors and doctoral programs. IZA engages in (i) original and internationally competitive research in all fields of labor economics, (ii) development of policy concepts, and (iii) dissemination of research results and concepts to the interested public.
\end{abstract}

IZA Discussion Papers often represent preliminary work and are circulated to encourage discussion. Citation of such a paper should account for its provisional character. A revised version may be available directly from the author. 
IZA Discussion Paper No. 2223

July 2006

\section{ABSTRACT \\ Globalisation, Inequality and Poverty Relationships: A Cross Country Evidence}

In this research, the relationship between globalisation and poverty and income inequality is determined. A whole new globalisation index has been constructed based on data covering a large sample of 65 developing countries. The index is based on the globalisation index proposed by A.T. Kearney / Foreign Policy Magazine. The index is composed of four subindices, namely: economic integration, personal contacts, technological connections and political engagement. Results from cross-sectional regression analysis show that there is a significant relationship between globalisation and poverty and income inequality. Globalisation leads to poverty reduction and it reduces income inequality. The relationship between globalisation and poverty remains significant when controlled for regional heterogeneity. A non-linear analysis shows that poverty has diminishing returns to benefits from globalisation.

JEL Classification: C43, F15, O57

Keywords: $\quad$ globalisation, poverty, inequality, indices

Corresponding author:

Almas Heshmati

Techno-Economics and Policy Program

College of Engineering

Seoul National University, \#37:321

San 56-1 Shinlim-Dong, Kwanak-Gu

Seoul 151-742

South Korea

E-mail: Heshmati@snu.ac.kr 


\section{THE DEBATE ON GLOBALISATION AND POVERTY}

The book of the International Forum of Globalization with the title "Does globalization help the poor?” answers this question with a confident 'no'. The back cover of Bhalla's (2002) book, “Imagine there's no country: poverty, inequality and growth in the era of globalization”, asks: 'Who has gained from globalization?' and answers with equal confidence: 'the poor'. Yet readers of neither book will come away any wiser about the answer to these questions than when they started." (Ravaillon, 2003)

Globalisation and poverty is a highly debated topic in the literature. Various studies prove that globalisation increases poverty, whereas numerous other studies claim that globalisation reduces poverty. Those in favour of globalisation claim that there have been significant steps in the fight against global poverty, as well as a decrease in inequality in the last 20 years, and that liberalization of economic policies or globalisation has been responsible for this achievement. In contrast there are the critics who claim that globalisation has led directly to increases in poverty and inequality. The rich are getting richer and the poor are getting poorer. Both sides have backed up their claims with 'facts', but instead of a clear debate and clear cut studies and conclusions, there has been an increasingly complex 'numbers debate'.

One of the main contributors to the debate is the World Bank. In the publication Globalization, Growth and Poverty (2002), it is claimed that globalisation generally reduces poverty because more integrated economies tend to grow faster and this growth is usually widely diffused.

“As low-income countries break into global markets for manufactures and services, poor people can move from the vulnerability of grinding rural poverty to better jobs, often in towns or cities. In addition to this structural relocation, integration raises productivity job by job. Workers with the same skills, be they farmers, factory workers, or pharmacists, are less productive and earn less in developing economies than in advanced ones. Integration reduces these gaps”. (Dollar and Collier, 1999)

The basis of the results from the report of the World Bank is the study of Dollar and Kraay (2001). In this study they define globalisation based on growth in trade relative to GDP in constant prices and based on the reductions in average tariff rates. 
They give an answer to the common concern whether openness or globalisation is leading to growing inequality within countries and that therefore the poor are benefiting less or even not at all from these developments. Their conclusions are twofold. First, openness is associated with higher growth. Second, increased trade is not associated, on average, with a systematic tendency to increased inequality. The poor share in growth is proportional to their existing share of national income. The combination of higher growth and no change in income distribution translates into more rapid poverty reduction.

There have been some extensive critiques of Dollar's work. One of the first issues is Dollars position on the development of world inequality. Dollar argues that global inequality has declined slightly since 1980. Milanovic (1999) argues that this is only true when the average per capita income is weighted by population. His results show that when China and India are dropped from the sample inequality actually increases. Inequality in China is increasing, but the level is below average global level.

Watkins (2002) reached a similar conclusion that increased trade is not associated with a systematic tendency to increased inequality. Another more serious problem, Watkins states, is the problem concerning what is being measured. The implicit assumption Dollar and Kraay make that trade liberalization is responsible for successful integration, with success defined as faster growth and poverty reduction, is little more than a speculative leap of faith.

“Countries such as China, Thailand, and Vietnam may be premier globalisers. They also have a strong record on economic growth and poverty reduction. Yet they have liberalized imports very slowly and still have relatively restrictive trade barriers. Conversely, countries such as Brazil, Haiti, Mexico, Peru, and Zambia have been worldbeaters when it comes to import liberalization, but have a weak record on growth and poverty reduction. In short, many first-rate globalisers have fifth-rate records on poverty reduction”. (Watkins 2002).

Wade (2004) uses the same arguments as Watkins and also doubts the fact that globalisation is a positive force for poverty reduction. He doubts that the rising quantity of trade and the developmental benefits thereof, are the consequences of trade liberalisation. Finally, he questions the assumption that fast trade growth is the major cause of good economic performance. 
So far we have summarised to some extent the debate on globalisation and poverty, fuelled by the work of Dollar. It seems that the pro-globalisation camp and contra- globalisation camp, or defined by Watkins as the "globaphilia's" and "globaphobia's”, will not reach a consensus in the near future.

Besides the studies showing a merely positive or negative relationship between poverty and globalisation there are also studies showing a more subtle relationship, which argues that in some cases globalisation can favour poverty reduction and some situations will worsen poverty.

One of the authors is Agénor (2002). In his paper he examines the extent to which globalisation affects the poor in developing countries. He defines globalisation in terms of trade openness and financial openness, respectively measured as a tariff revenue imports ratio and foreign direct investments. He argued that the exports and imports relative to GDP measure should be excluded from the trade openness component because of its excessive sensitivity to short run fluctuations. He then tested the presence of a non-linear relationship between openness and poverty. To assess the relationship he used a cross-country regression framework, using unbalanced panel data for 30 developing countries. His results show that there appears to be a reasonably robust inverted U-shape relationship between poverty and globalisation. At low degrees of globalisation, globalisation does hurt the poor. However, at higher levels, globalisation leads to a decline in poverty.

Another author, Jagdish Bhagwati (2001) argues that globalisation influences poverty through its influence on growth. He points out that some types of growth will help the poor more than others, depending on the presence of other factors including policy distortions that reinforce or reduce the effect of growth on the poor. It is also clear from his analysis of the link between trade and growth that the effect of globalisation on growth could vary across countries and over time for similar reasons. Above all, he argues, since trade and other policies, as well as their outcomes in terms of growth and poverty are endogenous, it is hard to draw valid inferences without a well-specified analytical and econometric framework.

It is clear from the discussion that when globalisation is related to poverty, globalisation is usually treated as a concept of economic and financial integration. To 
date, there are not many studies that consider the possibility that globalisation could, or maybe should, be viewed as a wider concept.

Heshmati (2004) is the first to relate poverty and inequality to a different definition of globalisation, or more precisely, an extended definition. He used a globalisation index proposed by AT Kearney / Foreign Policy Magazine (2002, 2003). It is the first attempt to construct a database and to compute a composite globalisation index. The index is composed of four main indices: economic integration, personal contacts, technological connections and political engagement, measured by 13 indicators. This index will be discussed in more detail in the next chapter.

Heshmati (2004) has used this index to measure the relationship between income inequality, poverty and globalisation. By making use of panel data to compute globalisation index and conducting cross sectional regression analysis he shows that there is an indication that the relationship between globalisation and income inequality, measured as the GINI coefficient, is negative, meaning that high globalisation relates to low income inequality. His findings are however, statistically insignificant. The same applies when the relationship is tested for non-linearity, indicating the absence of a Kuznets U-shaped relationship.

So far, the results are not very clear cut. Studies trying to relate globalisation measured in terms of economic openness, financial integration and trade policies to poverty show various results. Some studies 'prove' that globalisation help the poor whereas others claim that globalisation is hurting the poor. When globalisation is placed in a broader perspective, like Heshmati's study, globalisation seems not to or relate weakly to poverty. Does this mean that we should no longer try to understand how globalisation relates to poverty and use our academic resources in other areas? In this paper we will try to shed some new light on the matter by extending the work of Heshmati. We believe that there is potential for the Kearney globalisation index, but that there should be some changes made to the index as well as to the data and the approach we take to relate poverty to that index.

We do this by increasing the sample size of the developing countries from 37 countries in Heshmati's research to a number of 65 countries, excluding the industrialized countries and extending the globalisation index by adding new indicators of globalisation. A broaden definition of globalization together with more homogenous 
sample of countries improves the possibility to estimate effects of globalization on poverty and inequality more precise.

First the index will be examined and discussed and changes, where necessary, are made by extending the index through inclusion of new variables like globalisation variables from the Technology Achievement Index and the Economic Freedom Index data sources. This extended index is then discussed to determine the levels of globalisation among the developing countries. After that, in the empirical part of the study, a linear regression of income inequality and poverty on the extended globalisation index is analysed. Finally a non-linear relationship is tested in an attempt to determine the globalisation index relating to poverty as previously studied by Agénor (2002) and Heshmati (2004).

Before these analyses are done, the next section (2) of this paper starts with the poverty measurement determination. Due to the debate on how to measure globalisation it might be easy to forget that measuring poverty is as important and not as easy as, one might expect. Section 2 presents the data, its sources and variable definitions. Analysis of globalization index is reported in Section 3. The models and estimation results are discussed in Section 4. Section 5 concludes.

\section{DATA}

In this section of the paper the data used for the empirical part is discussed. Section 2.1 discusses the data chosen to measure poverty and inequality. Section 2.2 discusses the sources of the globalisation index and the procedure for the index calculations. Finally, in section 2.3 we analyse the computed new globalisation index.

\subsection{Measures of Poverty and Inequality}

The fact that the choice of poverty and inequality measurement does matter is discussed by Ravaillon (2003). He argues that, roughly speaking, the more 'relative' the poverty measure; the less impact economic growth will have on its value. Those authors who say that globalisation is good for the world's poor tend to be 'absolutists'. By contrast, many critics of globalisation appear to think of poverty in more relative terms. 
At one extreme, if the poverty line is proportional to mean income then it behaves a lot like a measure of inequality. The conceptual ambiguities are not the only reason for the conflicting claims one finds in the globalisation debate. There are also differences in how the available data has been interpreted and differences in the underlying assumptions made in measurement.

It is outside the scope of this study to discuss in detail which poverty measurements are discussed in the literature and which measurements are considered the 'best' poverty measurements. First of all it is important to find those which provide the necessary data. We have chosen the poverty measurements used by the World Bank, as this measurement is widely used in literature and extensive data is available. These measures are the percentage of population living below one dollar and two dollars a day and the national poverty line. For income inequality the measurements discussed in Ray (1998) are selected. These are the Gini coefficient and the Kuznets ratio. Next, these measurements are briefly discussed. For a comprehensive discussion of data used in studies of economic growth, inequality, poverty and globalisation see Heshmati (2004).

There are two main ways of determining poverty lines; these are relative and absolute poverty lines. Relative poverty lines are defined in relation to the overall distribution of income or consumption in a country. Absolute poverty lines are anchored in some absolute standard of what households should be able to count on in order to meet their basic needs. The World Bank measures poverty in relative terms by the share of the population living below the national poverty line. In absolute terms poverty is measured by the share of population living below one dollar a day and two dollars a day. The proportion of population below $\$ 1$ per day is the percentage of the population living on less than $\$ 1.08$ a day at 1993 international prices. The proportion of population below $\$ 2$ per day is the percentage of the population living on less than $\$ 2.15$ a day at 1993 international price. The \$1 a day and \$2 a day poverty lines are compared to consumption or income per person and includes consumption from own production and income in kind. Because this poverty line has fixed purchasing power across countries or areas, the $\$ 1$ and $\$ 2$ a day poverty line is often called an "absolute poverty line”. (UNDG, 2003)

There are some disadvantages of this poverty measure. First of all, the PPP (purchasing power parity) exchange rates that are used are primarily designed for 
comparing aggregates from national accounts and may not fully reflect the comparative cost of goods typically consumed by the very poor. Other disadvantages are the comparability of poverty within countries, the unresolved issue about whether to use income or consumption as a welfare indicator, and the comparability across countries at different levels of development.

Poverty measures depend on the average level of income or consumption in a country and the distribution of income or consumption. Based on these two elements, poverty measures therefore focus on the situation of those individuals or households at the bottom of the distribution. Inequality is a broader concept than poverty in that it is defined over the entire population, not only below a certain poverty line.

The World Bank uses two income inequality measures, the Gini coefficient and the Kuznets ratio. The Gini coefficient takes the difference between all pairs of incomes and totals the (absolute) differences. The coefficient is normalized by dividing by population squared as well as mean income. This is the most commonly used measure of inequality. The coefficient varies between 0 , which reflects complete equality, and 1 , which indicates complete inequality.

If a society is most concerned about the share of income of the people at the bottom, a better indicator may be a direct measure, such as the share of income that goes to the poorest 10 or 20 percent. The measure percentage share of income or consumption is also called the Kuznets ratios. Simon Kuznets introduced these ratios in his study of income distributions in developed and developing countries. These ratios refer to the share of income owned by the poorest 20 or 40 per cent of the population or by the richest 10 per cent. The Kuznets ratio of the share of income owned by the poorest 20 percent of the population is used in this study.

For the purpose of this research these aforementioned measures are chosen. The data is collected from the World Bank. For poverty we now have the tools to relate poverty to globalisation and to compare absolute and relative poverty in relation to globalisation. The globalisation index is calculated for the year 2001 and in most cases this was possible for the poverty measures and income inequality measures as well. In some cases the data is from earlier periods. This implies that for certain countries the measures are assumed to be constant over time. 
For income inequality measures, the Gini coefficient and the Kuznets ratio are used supplying the measures to relate income inequality to globalisation. The data for the Gini coefficient and the Kuznets ratio are collected from the World Bank. Most data is collected in the years between 1999 and 2001, with some exceptions where data is from between 1995 and 1999.

Now that the definitions and measurements of poverty and income inequality have been established lets continue with the analyses of the globalisation index in the next sub-section.

\subsection{Sources of the Globalisation Index}

Originally, the Kearney globalisation index is constructed for 62 countries, including 25 developed and 37 developing countries. It is built by four main sub-indices which are economic integration, personal contacts, technological connections and political engagement. Together these sub-indices form the overall Kearney globalisation index. The economic integration index is constructed by economic data that relates to the economic openness of a country. It includes data on international trade, foreign direct investments, international portfolio capital flows and international income payments and receipts.

The personal contacts index is built by data on the level of international contacts of country inhabitants with the rest of the world. Data on international travel and tourism and cross-border transfers are collected to construct this index. The third index is the technological connections of a country with the global world. This is measured by the number of secure internet servers, internet users and internet hosts. The last index is the political engagement of a country measured by its participation in Security Council missions of the United Nations, its membership in international organisations and the number of embassies abroad.

For the purpose of this study the Kearney globalisation index is adapted in two ways. First of all the developed countries are excluded from the database and 28 developing countries are added. This increases the set of developing countries from 37 to 65 . The second change is the extension of the index components to include more indicators of globalization, described next. 
The strength of the Kearney globalisation index is that it not only takes economic factors into account, such as trade and direct foreign investments, but also non-economic factors, such as the involvement and cooperation of countries in the world political arena. Further more, it recognises the importance of the technical development of a country and its ability to develop further. Finally, it also includes the possibilities of a country's inhabitants to connect to the global world. However, there are also limitations to this globalisation index. In another paper, Heshmati (2006) criticised the design of the index with respect to the selected components and suggested additional elements to the globalisation index. Among these suggestions are additional sub-indices relating to standards of living in countries, environmental issues, wage inequality, democracy and conflict, access to information and flows and directions of movement of goods and skilled labour between countries. Although the critics are valid, Heshmati (2006) is much too focussed on adding new sub-indices to the overall index and less to take a critical look at the existing sub-indices. Further more, the suggested improvements are a mixture both elements of globalisation and expected products of globalisation.

This study is designed to develop the existing index further by taking a closer look at the sub-indices of the overall index. In the next part of this research the existing components of the sub-indices are examined and new components or indicators of globalization are presented and added to the index.

The first sub-index is the economic integration index. The original index includes international trade, foreign direct investments, portfolio capital flows and income payments and receipts. They give a good description of countries economic involvement in the global world. However, important legal and regulatory elements that influence economic freedom are omitted from the index. Therefore, we extend these components with the freedom to trade internationally index, part of the Index of Economic Freedom constructed by the Heritage Foundation / Wall Street. The index is built by the variables: taxes on international trade, regulatory trade barriers, actual size of trade sector compared to expected size, difference between official exchange rate and black market rate and international capital market controls. Most of these measures are of a policy nature. It could be expected that some of these policy measures are already somehow included in the economic integration variables and therefore are already 
reflected in the other components. However, Kraay, Zoido-Lobaton and Kaufmann (1999) showed that a tariff rate is a policy variable, and that the relationship between tariff rates and trade volumes is not that strong. Given this result we expect that the freedom indicators have additional information beyond the volume of trade.

The personal contacts component is also adapted. The initial variables of international travel and tourism and cross-border transfers are kept. In the Kearney globalisation index the measure of international telephone traffic is also included, but due to the problems of retrieving this data it is left out in the calculations of the original index in this study. Alternatively, the number of internet users is used. Internet users are connected to the rest of the world and it enables them to contact people from all over the world. This component was part of the technological connections in the Kearney index. It has been taken out of that component because of the over representation of the internet technology in the technical connections index.

The technological connections index has been changed drastically. In the Kearney Index the technology connections index is mainly based on internet technology. It measured the secure internet servers, internet users and internet hosts. But doesn't technological advancement include much more than the internet? The shift from ploughing land with an ox to ploughing with high-tech farming equipment is not just made by accessing the internet. Access to this equipment and the ability to use it is necessary. The World Bank has attempted to include additional aspects of technology in its Technology Achievement Index published in the World Development Report of 2001. The aim of the index is to capture how well a country is creating and diffusing technology and building a human skill base - reflecting the capacity build up necessary infrastructure for development and to participate in the technological innovations of the network age.

We have chosen parts of the index which relates to globalisation. These are the number of patents granted to non-residents per capita, the receipts of royalty and license fees from abroad per capita, the internet hosts per capita and the export of high technology products as a share of manufactured exports.

The last component, political engagement remains intact. No variable has been removed and no variable has been added. Until now, no better alternative has been found to improve this part of the globalisation index. 
Table 1: Globalisation indicators and globalization index components

\begin{tabular}{|c|c|c|c|}
\hline VARIABLE & MEASURE & $\begin{array}{l}\text { ABBRE- } \\
\text { VIATION }\end{array}$ & DATA SOURCES \\
\hline $\begin{array}{l}\text { Economic } \\
\text { integration }\end{array}$ & $\begin{array}{l}\text { International Trade } \\
\text { Foreign Direct Investments } \\
\text { Portfolio Capital Flows } \\
\text { Income Payments and } \\
\text { Receipts } \\
\text { Freedom to trade } \\
\text { international }\end{array}$ & $\begin{array}{l}\text { IT } \\
\text { FDI } \\
\text { PCF } \\
\text { IPR } \\
\text { FTT }\end{array}$ & $\begin{array}{l}\text { IMF - International Statistics Browser } \\
\text { IMF - International Statistics Browser } \\
\text { IMF - International Statistics Browser } \\
\text { IMF - International Statistics Browser } \\
\text { HF/WS - Index of Economic Freedom }\end{array}$ \\
\hline $\begin{array}{l}\text { Personal } \\
\text { contacts }\end{array}$ & $\begin{array}{l}\text { International travel and } \\
\text { tourism } \\
\text { cross-border transfers } \\
\text { internet users }\end{array}$ & $\begin{array}{l}\text { ITT } \\
\text { CBT } \\
\text { IU }\end{array}$ & $\begin{array}{l}\text { TUI - Compendium of Tourism Statistics } \\
\text { IMF - International Statistics Browser } \\
\text { WB - World Development Indicators }\end{array}$ \\
\hline $\begin{array}{l}\text { Technological } \\
\text { connections }\end{array}$ & $\begin{array}{l}\text { Number of patents granted } \\
\text { to non-residents } \\
\text { Receipt of royalties and } \\
\text { license fees } \\
\text { internet hosts } \\
\text { export of high technology }\end{array}$ & $\begin{array}{l}\text { PN } \\
\text { RRL } \\
\text { IH } \\
\mathrm{EH} \\
\end{array}$ & $\begin{array}{l}\text { UNDP - Human Development Report } \\
\text { UNDP - Human Development Report } \\
\text { WRI - Earth Trends } \\
\text { UNDP - Human Development Report }\end{array}$ \\
\hline $\begin{array}{l}\text { Political } \\
\text { engagement }\end{array}$ & $\begin{array}{l}\text { International missions } \\
\text { International Organisations } \\
\text { Embassies }\end{array}$ & $\begin{array}{l}\text { IM } \\
\text { IO } \\
\text { E }\end{array}$ & $\begin{array}{l}\text { UN - Peace Keeping Missions } \\
\text { CIA - World Fact Book } \\
\text { The Europa World Yearbook }\end{array}$ \\
\hline
\end{tabular}

In Table 1 the various measures and sources used for the globalisation index are presented. These are the measures that are used to construct each sub-index. The globalisation index is constructed through normalising each variable through a process that assigns values to data points relative to the maximum value. It should be noted that the normalization here differs from the original formula (se Heshmati, 2006) by using ratios in which the lowest score is not limited to zero. In Table 2 some results from the calculations are presented.

Table 2: Main calculations globalisation index

\begin{tabular}{llllll}
\hline Variables & $\mathrm{N}$ & Minimum & Maximum & Mean & Std.Dev. \\
\hline EI & 65 & 0.167 & 0.733 & 0.342 & 0.120 \\
\hline PC & 65 & 0.034 & 0.555 & 0.170 & 0.125 \\
\hline TC & 65 & 0.001 & 0.552 & 0.112 & 0.115 \\
\hline PE & 65 & 0.193 & 0.991 & 0.471 & 0.193 \\
\hline GI & 65 & 0.523 & 2.040 & 1.090 & 0.332 \\
\hline
\end{tabular}

$\mathrm{EI}=$ economic integration, $\mathrm{PC}=$ personal contacts, $\mathrm{TC}=$ technological connections, $\mathrm{PE}=$ political engagement, GI = globalisation index 
The overall globalisation index scores for every country are derived by adding the four separate sub-indices. Each indicator is given the same weight. For alternative parametric approaches allowing different weights see Heshmati (2006).

The formula that is used to calculate the economic integration index is:

$$
\begin{aligned}
E I_{i}= & \left(\left(I T_{i} / G D P_{i}\right) /\left(I T_{\max } / G D P_{\max }\right)+\left(F D I_{i} / G D P_{i}\right) /\left(F D I_{\max } / G D P_{\max }\right)\right. \\
& +\left(P C F_{i} / G D P_{i}\right) /\left(P C F_{\max } / G D P_{\max }\right)+\left(I P R_{i} / G D P_{i}\right) /\left(I P R_{\max } / G D P_{\max }\right) \\
& \left.+\left(F T T_{i} / F T T_{\max }\right)\right) / 5
\end{aligned}
$$

The definitions of the abbreviations are presented in Table 1 . The subscript $i$ refers to the country and max to the maximum value of the particular measure for the whole set of countries.

Similarly, the personal index is defined by:

$$
\begin{aligned}
P C_{i} & =\left(\left(I T T_{i} / P O P_{i}\right) /\left(I T T_{\max } / P O P_{\max }\right)+\left(C B T_{i} / G D P_{i}\right) /\left(C B T_{\max } / G D P_{\max }\right)\right. \\
& \left.+\left(I U_{i} / P O P_{i}\right) /\left(I U_{\max } / P O P_{\max }\right)\right) / 3
\end{aligned}
$$

And the technological connections index is defined by:

$$
\begin{aligned}
T C_{i} & =\left(\left(P N_{i} / P O P_{i}\right) /\left(P N_{\max } / P O P_{\max }\right)+\left(R R L_{i} / G D P_{i}\right) /\left(R R L_{\max } / G D P_{\max }\right)\right. \\
& +\left(I H_{i} / P O P_{i}\right) /\left(I H_{\max } / P O P_{\max }\right) \\
& \left.+\left(E H_{i} / E_{\text {EXORTS }}\right) /\left(E H_{\max } / E_{\text {XPORTS }}\right)\right) / 4
\end{aligned}
$$

Finally, the political engagement index is defined by:

(4)

$$
P E_{i}=\left(\left(I M_{i} / I M_{\max }\right)+\left(I O_{i} / I O_{\max }\right)+\left(E_{i} / E_{\max }\right)\right) / 3
$$

The overall globalisation index (GI) is than calculated by adding the four index components:

$$
G I_{i}=\left(E I_{i}+P C_{i}+T C_{i}+P E_{i}\right)
$$


In the next part of this section we will analyse the structure of the globalisation index. From the literature we have seen that so far the definition and quantification of globalisation been mainly limited to economic globalisation. Measures of trade and financial flow are the basis of the analyses of globalisation and poverty. Until now, only Heshmati (2004) has attempted to relate globalisation and poverty using a wider definition. However, he did not study the additional information the sub-indices add to economic integration. It is important to give an answer to the question of whether the globalisation index, through the four sub-indices, delivers additional insight into globalisation and poverty relationships. We can examine this by concentrating on the relationship between economic integration and the other sub-indices as well as the total extended globalisation index. A detailed analysis is given in Appendix A. The conclusion from the analysis is that all three sub-indices and the overall globalisation index give additional information to economic integration.

In this section we discussed the sources of the globalisation index and the method to calculate the index. We also showed that the globalisation index supplies additional information to globalisation measured as economic integration, which has used mostly in the literature so far. In the next section we will analyse the index in more details.

\section{ANALYSIS OF THE GLOBALISATION INDEX}

In this section we will take a closer look at the ranking of the countries on the overall globalisation index. After that, an analysis is made of the globalisation index relating to some economic and country figures.

\section{A Rankings of the countries}

Figure 1a and 1b show the rankings of the developing countries in the overall globalisation index decomposed into different sub-indices. The total graph is cut up in two parts in order to show the differences between countries that are located close to each other on the index. The results show that Estonia is the most globalised country of 
the developing nations, followed by the Czech Republic and Malaysia. Estonia, Czech Republic, Croatia, Slovenia, Slovak Republic and Poland are new members of the European Union and subsequently much more developed in 2006 than they were in 2001.

Burundi is the least globalised country next to Madagascar and Rwanda. It is interesting to see that the political engagement seems to have a large impact on the globalisation index. This is especially the case for Russia, China, Egypt and Kenya in the upper sector of the globalisation index. In the lower sector of the index political engagement seems to have a large impact on India, Pakistan and Bangladesh. It is difficult to determine why this part of the index is so important. It might be explained by the fact that distribution of the political component is more equal and it constitutes one forth of the overll index for the most globalized country serving as reference country. Later on the detailed relationships between the sub-indices will be tested in relation to poverty and income inequality.

Figure 1a: Extended globalisation index 2001 (most globalised countries)

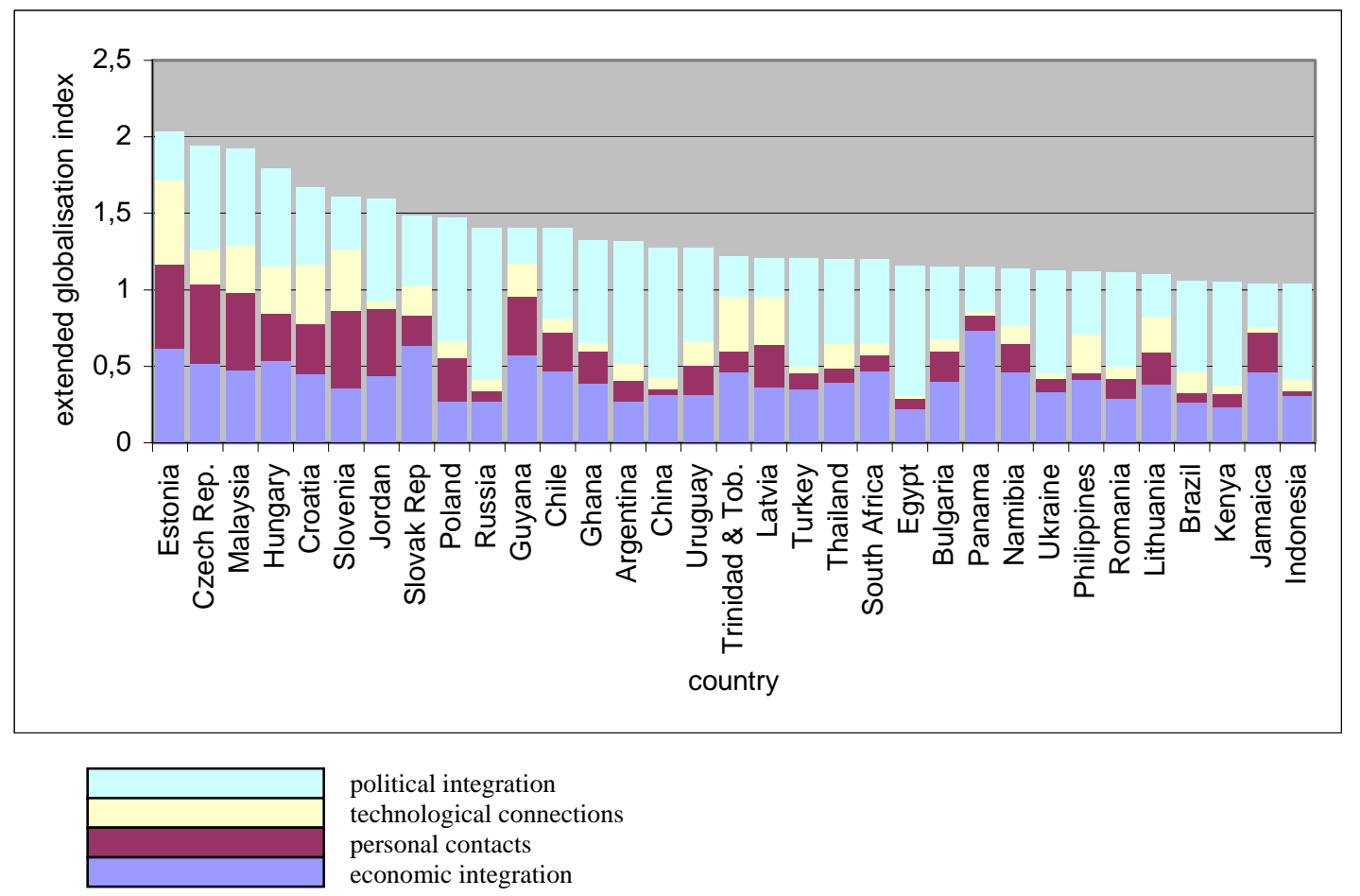


Figure 1b: Extended globalisation index 2001 (least globalised countries)

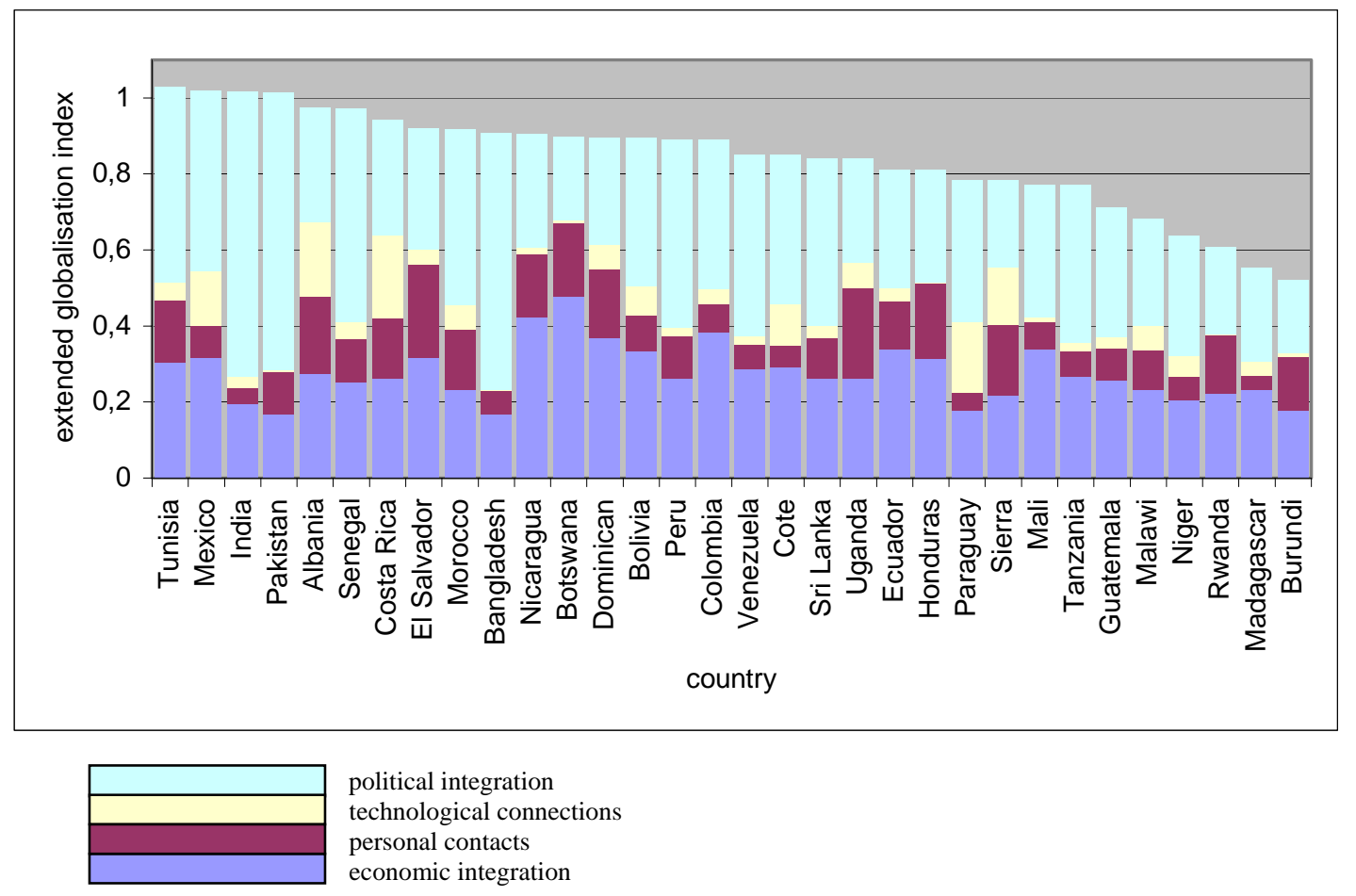

For the first time we have a globalisation index for a large number of developing countries. This offers the opportunity to see how globalisation relates to poverty and inequality. But before we continue with that analysis we will make use of the opportunity to see how globalisation relates to some other economic and country figures.

\section{B Relationship between globalization and economic development}

First of all we concentrate on the relationship between globalisation and GDP per capita. One of Dollar's conclusions is that the poor countries that have reduced trade barriers and participated more in international trade over the past twenty years have seen their GDP growth rates accelerate. At the same time the developing countries that are not participating in globalisation are falling further and further behind.

With the new globalisation index we can partially test the conclusions of Dollar. Instead of concentrating on the economic openness of a country we are able to test whether the same conclusion can be drawn when using the globalisation index. Therefore, in Figure 2, the relationship between globalisation and GDP per capita is 
shown. From the graph we see that the globalisation index is positively relating to GDP per capita. It shows that countries with low levels of GDP per Capita are also low on the globalisation index and vice versa. There are no particular countries that show surprising results. Slovenia is the only country that seems to be somewhat less globalised than one might expect regarding the size of its economy. Therefore, Dollar's link between globalisation and GDP has also been established when using the globalisation index.

Figure 2: Globalisation and GDP per Capita

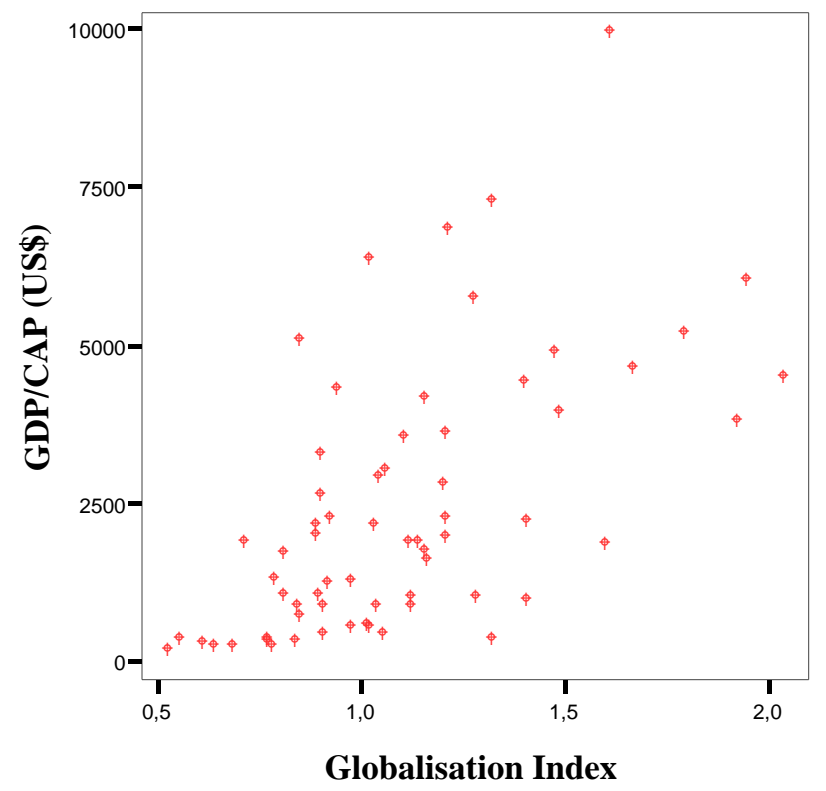

Source: World Bank, Year: 2001

\section{C Relationship between globalization and size of country}

Next, we turn to the relationship between globalisation and the size of a country in terms of population. It is sometimes argued that large countries tend to be less globalised than smaller countries due to their ability to depend on their own strength and market size. Prasad, Rogoff, Wei and Ayan Kose (2003) argue that small developing states are relatively more open to trade implying that they are generally more reliant on export earnings than other developing countries. They also tend to be 
less diversified in terms of production structure and export base. While small states have been developed strong trade linkages with the global economy, their financial linkages are weaker.

A clear cut relationship between the size of a country in terms of population and globalisation is not present. The larger countries do not score significantly lower on the globalisation index than the smaller countries do. In Figure 3 the relationship is shown. China and India are to be considered as outliners in this respect and subsequently excluded because their population is of such a size that the graph would be difficult to interpret.

Figure 3: Globalisation and Population

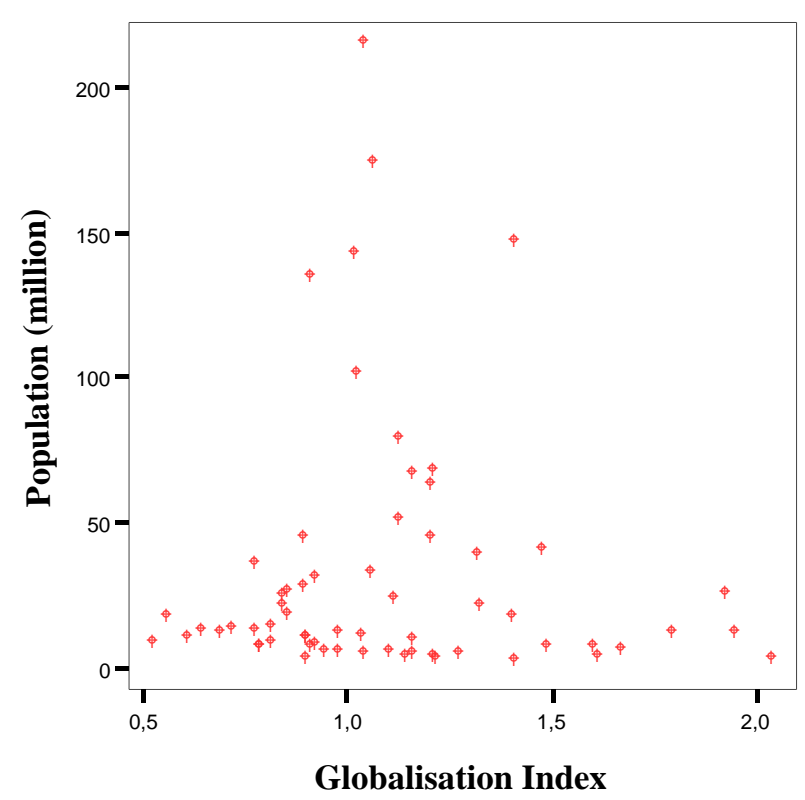

Source: International Monetary Fund, Year: 2001

\section{D Relationship between globalization and regional location}

The final relationship we will analyse in this section is the relationship between globalisation and the geographical region. What happens if we divide the developing countries into different regions? Heshmati (2004) concluded that regional heterogeneity has a greater effect on levels of poverty than globalisation has. It might be interesting to see how the regions relate to globalisation. Are countries in a similar region, globalised 
in a similar way? It should be noted that in Heshmati the sample contains OECD countries, while the industrialized OECD countries are excluded in current sample. Our sample of developing countries is more homogenous reducing regional heterogeneity.

In order to study this, the developing countries can be divided in different geographical regions also determined by the World Bank. These regions are East Asia and the Pacific (EA), Europe and Central Asia (EUR), Latin America and the Caribbean (LA), Middle East and North Africa (AR), South Asia (SA) and Sub-Saharan Africa (SSA).

In Figure 4 the relationship between globalisation and the geographical regions is displayed.

Figure 4: Globalisation and Geographical Regions

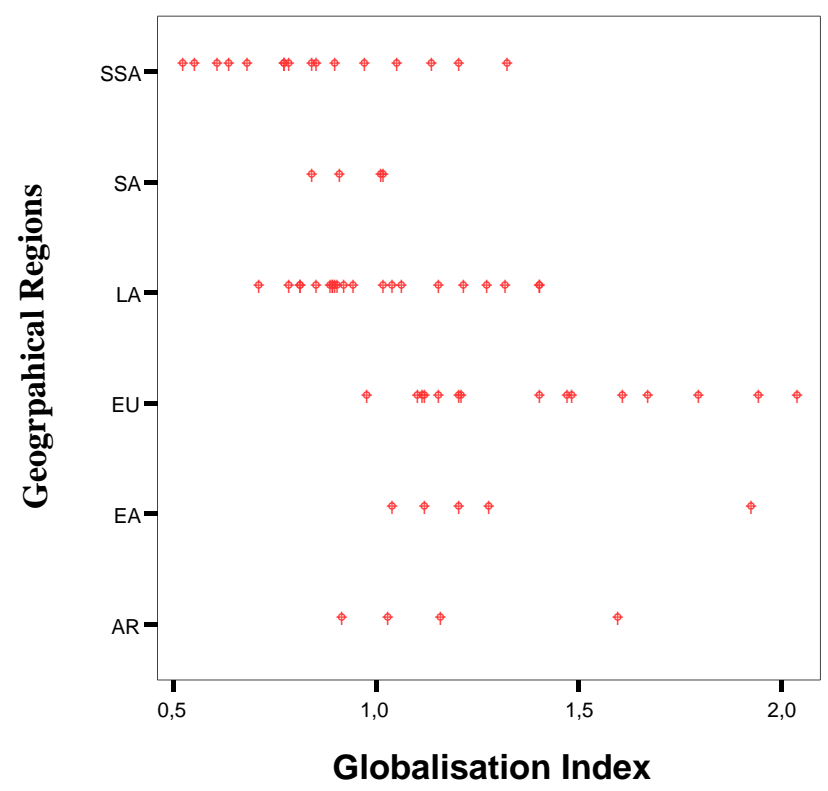

Source: World Bank, Year: 2001

We can see that in the Middle East / North Africa region the countries are relatively similar in levels of globalisation with the exception of Jordan. Jordan has a much higher level of globalisation compared to the other countries in the region. The same situation occurs for East Asia / Pacific. Similar globalisation levels can be found for all the countries, where Malaysia is the positive exception, with a much larger level of globalisation. 
Europe/Central Asia is much more divided. Although the countries in this region are quite highly globalised the differences in this region are rather large. A similar spread can be found in the Latin American region and the Sub-Saharan Africa region, Here the level of globalisation is lower than in Europe/Central Asia. The South Asian countries show much more similar levels of globalisation and can be found in the lowermedium level of the index. Overall we can conclude that there are differences in level of globalisation between the regions, but inter-regional the spread is quite large too. Therefore, the between regional factor alone does not seem to determine the differences in the level of globalisation.

So far we have analysed the globalisation index. We showed what positions each country has on the globalisation index and related the index to GDP per capita, population and geographical regions. Next, we will analyse the relationships between globalisation and poverty and income inequality.

\section{MODEL AND ESTIMATION RESULTS}

In this chapter the model is described and tested to relate poverty and income inequality to the extended globalisation index. In section 4.1 a linear regression is run, followed by a multiple regression, to determine the relationship between the sub-indices and globalisation. In section 4.2 a quadratic-regression is shown in order to determine non-linearity in the relationship between globalisation, inequality and poverty. Sensitivity analysis is made with respect to different definitions of inequality and poverty and different sub-indices of globalisation.

\subsection{Linear Regression analysis}

First a cross-sectional regression is run to determine the relationship between poverty and income inequality and the extended globalisation index. We use a crosssectional regression analysis using globalisation data for 2001 and poverty and inequality data for 2001, where available.

Five regression formulas are used to relate globalisation to poverty and inequality. Each regression analysis uses the extended globalisation index as the 
explanatory variable but the poverty and income inequality variables are different. Model A1 represents the \$1 poverty line variable, model A2 the \$2 poverty line, model A3 the percentage of the population below the national poverty line, model A4 the income inequality measured by the Kuznets ratio and model A5 represents income inequality in terms of the Gini coefficient. In table 3 an overview of the variables is given for this model and the other regression models in this study.

Table 3: Poverty and inequality variables in the regression models

\begin{tabular}{|l|l|l|l|l|}
\hline Model 1 & Model 2 & Model 3 & Model 4 & Model 5 \\
\hline 1\$ poverty line & 2\$ poverty line & $\begin{array}{l}\text { National poverty } \\
\text { line }\end{array}$ & Kuznets ratio & Gini coefficient \\
\hline
\end{tabular}

Model A1: $\quad$ POVERTY1 $_{i}=\alpha_{1}+\beta_{1} \operatorname{GINDEX}_{i}+\varepsilon_{1}$

Model A2: $\quad$ POVERTY2 $_{i}=\alpha_{2}+\beta_{2}$ GINDEX $_{i}+\varepsilon_{2}$

Model A3: $\quad$ POVERTY $_{i}=\alpha_{3}+\beta_{3}$ GINDEX $_{i}+\varepsilon_{3}$

Model A4: $\quad$ INEQUALITY $1_{i}=\alpha_{4}+\beta_{4}$ GINDEX $_{i}+\varepsilon_{4}$

Model A5: $\quad$ INEQUALITY $2_{i}=\alpha_{5}+\beta_{5}$ GINDEX $_{i}+\varepsilon_{5}$

The GINDEX refers to the globalisation index, $\varepsilon: s$ are random error terms and the subscript $i$ refers to a country.

The above regression formulas should give us insight into the unconditional relationship between globalisation and poverty and income inequality. The results in Table 4 show that the model in which poverty, measured as the one dollar poverty line and the two dollar poverty line, is statistically significant. With a beta of respectively 0.566 and -0.626 we see that there is a negative relation. This means that high globalisation levels relate to low poverty levels and vice versa. The relation between globalisation and poverty, measured as the national poverty line, is also statistically significant. With a beta of -0.640 this relation is also negative. In model A4 where inequality is measured as the Kuznets a positively significant relationship is found, with a beta of 0.418 . Finally, model A5, with the Gini coefficient as the poverty variable, shows a statistically significant negative relationship with globalisation. The number of observations differs due to missing observations on poverty and inequality. 
Table 4: Regression

\begin{tabular}{llllll}
\hline Variables & Model A1 & Model A2 & Model A3 & Model A4 & Model A5 \\
\hline \multirow{2}{*}{ Constant } & 0.562 & 0.974 & 72.069 & 0.025 & 57.812 \\
& $(7.466)^{* *}$ & $(9.733)^{* *}$ & $(10.708)^{* *}$ & $(2.548)^{*}$ & $(13.084)^{* *}$ \\
\hline \multirow{2}{*}{ Globalisation Index } & -0.566 & -0.626 & -0.640 & 0.418 & -0.404 \\
& $(-5.451)^{* *}$ & $(-6.368)^{* *}$ & $(-5.833)^{* *}$ & $(3.531)^{* *}$ & $(-3.448)^{* *}$ \\
\hline R-square & 0.320 & 0.392 & 0.410 & 0.174 & 0.163 \\
\hline No. of observations & 65 & 65 & 50 & 60 & 62 \\
\hline
\end{tabular}

Note: t-statistics in parentheses. ${ }^{* *}$, * denote significance at the 1 and 5 percent levels (two-tailed tests).

When poverty is defined as the one dollar poverty line, 32 percent of the variance in poverty can be explained by the globalisation index. About 39 percent of the variance in poverty, defined as the 2 dollar poverty line, can be explained by the globalisation index. When poverty is measured in relative terms, the percentage of the population living below the national poverty line, 41 percent of the variation is explained by globalisation.

About 17 per cent of the variation in income inequality, measured as the percentage of the 20 per cent with the lowest national incomes or levels of consumption, is explained by globalisation. From the last model we learn that 16 percent of this variation in income inequality, measured by the Gini coefficient, is explained by globalisation. The explanatory power of the models based on a homogenous sample of developing country is much higher than in Heshmati (2006) who used a mixed sample of industrialized and developing countries.

What do we learn from these results? First of all, that the relationship between poverty and income inequality and globalisation is clearly established. High poverty and low income inequality relate to high levels of globalisation. The relationship is statistically significant and reasonably strong. This is quite a surprising result, regarding the debate in the literature. It is in line with the results of Dollar, but in contrast to many critics. The results also show that there is no significant difference when poverty is measured in relative or absolute terms, contradicting Ravaillion (2003), who claims that it seems that globalisation has less impact when measured in relative terms than when measured in absolute terms.

Furthermore, the relationship between the three poverty measures and globalisation is stronger than the relationship between globalisation and the two income inequality measures. Finally, whereas Heshmati (2004) could not find a significant relationship, these results do show a significant relationship. The differences might be 
due to differences in the country samples and the fact that Heshmati's study is based on a panel data covering 1995-2000, while current data is only a cross section of developing countries observed around 2001.

A noticeable result Heshmati (2004) found in his study is that when he controlled for regional heterogeneity, the explanatory power of his models relating globalisation to inequality increases significantly. However, the regional variable plays such an important role in his models in the explanation of variation in inequality that the globalisation coefficient becomes insignificant. The two effects are confounded and difficult to separate.

In the next analysis we will include also a regional dummy in order to see whether the found link to earlier analysis between globalisation and poverty and inequality holds. For this analysis the regression formulas become:

Model B1: $\quad$ POVERTY1 $_{i}=\alpha_{1}+\beta_{1}$ GINDEX $_{i}+\lambda_{1}$ REGION $_{i}+\varepsilon_{1}$

Model B2: $\quad$ POVERTY2 $_{i}=\alpha_{2}+\beta_{2}$ GINDEX $_{i}+\lambda_{2}$ REGION $_{i}+\varepsilon_{2}$

Model B3: $\quad$ POVERTY $_{i}=\alpha_{3}+\beta_{3}$ GINDEX $_{i}+\lambda_{3}$ REGION $_{i}+\varepsilon_{3}$

Model B4: $\quad$ INEQUALITY $_{i}=\alpha_{4}+\beta_{4}$ GINDEX $_{i}+\lambda_{4}$ REGION $_{i}+\varepsilon_{4}$

Model B5: $\quad$ INEQUALITY2 $2_{i}=\alpha_{5}+\beta_{5}$ GINDEX $_{i}+\lambda_{5}$ REGION $_{i}+\varepsilon_{5}$

The results in Table 5 show that poverty measures as the one dollar poverty line, the two dollar poverty line and the national poverty line all have a negative significant relationship to globalisation with respectively beta's of $-0.255,-0.330$ and -0.374 . The $\mathrm{R}^{2}$ of the model increases from 0.320 in model $\mathrm{A} 1$ to 0.663 in model $\mathrm{B} 1$. The $\mathrm{R}^{2}$ in model B2 increases from 0.392 in model A2 to 0.763 . Model B3 also shows a large increase in the $\mathrm{R}^{2}$ from 0.410 in model A3 to 0.589 in model B3.

Table 5: Regression including regional dummy variables

\begin{tabular}{llllll}
\hline Variables & Model B1 & Model B2 & Model B3 & Model B4 & Model B5 \\
\hline Globalisation Index & -0.255 & -0.330 & -0.374 & 0.034 & 0.015 \\
& $(-2.522)^{*}$ & $(-3.894)^{* *}$ & $(-2.917)^{* *}$ & $(0.341)$ & 0.147 \\
\hline Europe and Central Asia & 0.241 & 0.499 & 50.68 & 0.0777 & 30.141 \\
(reference) & $(2.486)^{*}$ & $(4.376)^{* *}$ & $(4.647)^{* *}$ & $(7.265)^{* *}$ & $(5.886)^{* *}$ \\
\hline Latin America and & 0.076 & 0.095 & 0.180 & -0.868 & 0.862 \\
Caribbean & $(0.673)$ & $(0.994)$ & $(1.121)$ & $(-7.658)^{* *}$ & $(7.307)^{* *}$ \\
\hline
\end{tabular}




\begin{tabular}{llllll}
\hline South Asia & 0.135 & 0.341 & 0.048 & 0.080 & 0.046 \\
& $(1.493)$ & $(4.505)^{* *}$ & $(0.391)$ & $(0.897)$ & $(0.487)$ \\
\hline Sub Saharan Africa & 0.702 & 0.694 & 0.447 & -0.603 & 0.777 \\
& $(5.789)^{* *}$ & $(6.830)^{* *}$ & $(2.673)^{*}$ & $(-5.213)^{* *}$ & $(6.400)^{* *}$ \\
\hline East Asia and Pacific & 0.094 & $0.279 * *$ & -0.060 & -0.270 & 0.321 \\
& $(1.102)$ & $(3.920)$ & $(-.511)$ & $(-3.231)^{* *}$ & $(3.626)^{* *}$ \\
\hline Middle East and North & -0.046 & 0.017 & -0.182 & -0.094 & 0.155 \\
Africa & $(-0.544)$ & $(0.232)$ & $(-1.575)$ & $(-1.118)$ & $(1.753)$ \\
\hline R-square & 0.663 & 0.763 & 0.589 & 0.695 & 0.646 \\
\hline No. of observations & 64 & 64 & 50 & 54 & 56 \\
\hline Note: t-statistics in parentheses. ${ }^{* *}, *$ denote significance at the 1and 5 percent levels (two-tailed tests).
\end{tabular}

The models B4 and B5 where globalisation is related to inequality show that with the inclusion of the regional dummies the globalisation coefficient becomes insignificant. In this case we can draw a similar conclusion as Heshmati (2004) did, that regional heterogeneity has such power in the model that globalisation does no longer significantly relate to inequality.

The next step in the analysis is to see which sub-index of the globalisation index shows the strongest relation to poverty, and with the technique of the backward selection method, it can be determined which sub-indices together determine the relationship between globalisation and poverty.

The technique begins by calculating $F$ statistics for the model, including all of the independent variables. Then the variables are deleted from the model one by one until all the variables remaining in the model produce $F$ statistics significant at the 0.10 level. At each step, the variable showing the smallest contribution to the model is deleted. For the analysis of the individual components in one model the following regression formulas are used:

Model C1: $\quad$ POVERTY1 $_{i}=\alpha_{1}+\beta_{E I} E I_{i}+\beta_{P C} P C_{i}+\beta_{T C} T C_{i}+\beta_{P E} P E_{i}+\varepsilon_{1}$

Model C2: $\quad$ POVERTY2 $2_{i}=\alpha_{2}+\beta_{E I} E I_{i}+\beta_{P C} P C_{i}+\beta_{T C} T C_{i}+\beta_{P E} P E+\varepsilon_{2}$

Model C3: $\quad$ POVERTY $_{i}=\alpha_{3}+\beta_{E I} E I_{i}+\beta_{P C} P C_{i}+\beta_{T C} T C_{i}+\beta_{P E} P E+\varepsilon_{3}$

Model C4: $\quad$ INEQUALITY1 $1_{i}=\alpha_{4}+\beta_{E I} E I_{i}+\beta_{P C} P C_{i}+\beta_{T C} T C_{i}+\beta_{P E} P E+\varepsilon_{4}$

Model C5: $\quad$ INEQUALITY2 $2_{i}=\alpha_{5}+\beta_{E I} E I_{i}+\beta_{P C} P C_{i}+\beta_{T C} T C_{i}+\beta_{P E} P E+\varepsilon_{5}$ 
The EI refers to economic integration, PC refers to personal contacts, TC refers to technological connections, $\mathrm{PE}$ refers to political engagement, $\varepsilon$ is the random error term and the subscript $i$ refers to a county.

First of all the models are tested for multicollenearity and shows that this is not present in the models. A correlation table is presented in Appendix B.

From Table 6 we see that in model C1, C2, and C3 the personal contacts are excluded from the regression analysis because of the backward selection parameters described above. In both models the three remaining sub-indices show a significant negative relationship between globalisation and poverty. In model C1 and C3 the personal engagement index is related strongest and in model B2 it is the technological connections. Model C4 has two sub-indices that relate positively; these are the personal contacts and political engagement. The political engagement relates the strongest.

The final model, C5, showed a negative relationship between globalisation, economic integration and technological connections, with technological connections being the strongest variable.

Table 6: Multiple regression

\begin{tabular}{|c|c|c|c|c|c|}
\hline Variables & Model C1 & Model C2 & Model C3 & Model C4 & Model C5 \\
\hline Constant & $\begin{array}{l}0.626 \\
(6.917) * *\end{array}$ & $\begin{array}{l}0.978 \\
(8.136) * *\end{array}$ & $\begin{array}{l}71.841 \\
(8.760)^{* *}\end{array}$ & $\begin{array}{l}0.022 \\
(2.643)^{*}\end{array}$ & $\begin{array}{l}56.605 \\
(15.271)^{* *}\end{array}$ \\
\hline Economic Integration & $\begin{array}{l}-0.313^{* *} \\
(-0.271)\end{array}$ & $\begin{array}{l}-0.370 * * \\
(-3.383)\end{array}$ & $\begin{array}{l}-0.220 * \\
(-1.740)\end{array}$ & .. & $\begin{array}{l}-0.334 * * \\
(-2.888)\end{array}$ \\
\hline Personal Contacts &.. & .. & .. & $\begin{array}{l}.302 * * \\
(2.690)\end{array}$ & .. \\
\hline Technological Connections & $\begin{array}{l}-0.291 * * \\
(-2.543)\end{array}$ & $\begin{array}{l}-0.379 * * \\
(-3.477)\end{array}$ & $\begin{array}{l}-0.332 * * \\
(-2.653)\end{array}$ & .. & $\begin{array}{l}-0.367 * * \\
(-3.173)\end{array}$ \\
\hline Political Engagement & $\begin{array}{l}-0.407 * * \\
(-3.939)\end{array}$ & $\begin{array}{l}-0.267 * * \\
(-2.715)\end{array}$ & $\begin{array}{l}-0.484 * * \\
(-4.299)\end{array}$ & $\begin{array}{l}.439 * * \\
(3.905)\end{array}$ & .. \\
\hline R-square & 0.365 & 0.425 & 0.413 & 0.269 & 0.213 \\
\hline No. of observations & 65 & 65 & 50 & 60 & 62 \\
\hline
\end{tabular}

The overall result is that the explanatory power of all five models increases when each sub-index is added into the regression model compared to the overall globalisation index tested in the A models.

The above results show quite a lot of differences between the 5 models. The subindices relate to the various poverty levels in different ways. To summarise, economic integration and technological connections affect all poverty measures, except for the 
Kuznets ratio. Personal contacts only relate to this poverty measure. Political engagement is an important determinant and relates to all measures except for the Gini coefficient.

It is also interesting to see that in none of the cases does economic integration relate strongest to poverty or inequality, indeed suggesting that there is more to globalisation than economic relationships between countries. When comparing these results with Heshmati's we see that the relationships are much stronger, which is probably due to the larger and homogenous set of developing countries used in this study.

\subsection{Non-linear Regression Analysis}

From the literature discussion we have seen that two authors have attempted to establish a non-linear relationship between globalisation and poverty.

First, Agenór found the existence of an inverted U-shape curve, and concluded that the peak of the quadratic equation would identify a "threshold" level of globalisation beyond which further integration reduces poverty. Heshmati (2004) also tried to determine a U-shaped relationship between inequality and globalisation. He found no significant results to identify this relationship. He did not test this relationship for poverty and globalisation. Can such a relationship be found in this research as well?

Oshima (1962) and Kuznets $(1955,1963)$ reasoned that economic progress, measured by per capita income, is initially accompanied by rising inequality, but that these disparities ultimately go away as the benefits of development diffuses more widely. When this idea is put graphically it looks like an upside down " $U$ ", and is therefore called the inverted-U hypothesis. (Ray, 1998)

In the ideal situation to test this hypothesis, countries should be tracked over time and the noted changes in inequality and poverty can than be used to test the hypothesis. However, reliable data is lacking and alternatives are needed to test the hypothesis. One alternative is to carry out a cross-sectional study. Although this method has many limitations, it does provide the opportunity to measure (for different countries) different stages of development. Paukert (1973) did one of the first such cross-sectional analyses. 
In this section we will test for a non-linear relationship by making use of a crosssectional analysis. To test for non-linearity a quadratic regression analysis is necessary. The regression formulas used are:

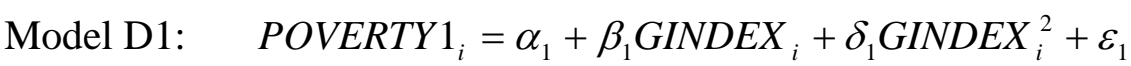

Model D2: $\quad$ POVERTY $2_{i}=\alpha_{2}+\beta_{2}$ GINDEX $_{i}+\delta_{2}$ GINDEX $_{i}^{2}+\varepsilon_{2}$

Model D3: $\quad$ POVERTY $3_{i}=\alpha_{3}+\beta_{3}$ GINDEX $_{i}+\delta_{3} \operatorname{GINDEX}_{i}^{2}+\varepsilon_{3}$

Model D4: $\quad$ INEQUALITY $1_{i}=\alpha_{4}+\beta_{4}$ GINDEX $_{i}+\delta_{4} \operatorname{GINDEX}_{i}^{2}+\varepsilon_{4}$

Model D5: $\quad$ INEQUALITY $2_{i}=\alpha_{5}+\beta_{5}$ GINDEX $_{i}+\delta_{5}$ GINDEX $_{i}^{2}+\varepsilon_{5}$

From the results in table 7 we see that between globalisation and poverty (model D1, D2 and D3) a significant relationship exists. Between globalisation and income inequality (model D4 and D5) the relationship is insignificant.

Table 7: Non-linear regression

\begin{tabular}{llllll}
\hline Variables & Model D1 & Model D2 & Model D3 & Model D4 & Model D5 \\
\hline Constant & 1.303 & 1.714 & 113.680 & 0.006 & 62.716 \\
& $(6.49)^{* *}$ & $(6.106)^{* *}$ & $(6.187)^{* *}$ & $(.192)$ & $(4.691)^{* *}$ \\
\hline Globalisation Index & -1.663 & -2.089 & -1.969 & 0.889 & -0.665 \\
& $(-4.923)^{* *}$ & $(-3.9398)^{* *}$ & $(-3.519)^{* *}$ & $(1.290$ & $(-0.976)$ \\
\hline Globalisation Index & 2.089 & 1.487 & 1.352 & -0.478 & 0.265 \\
& $(3.921)^{* *}$ & $(2.802)^{* *}$ & $(2.417)^{*}$ & $(-0.694)$ & $(0.389)$ \\
\hline R-square & 0.455 & 0.460 & 0.474 & 0.181 & 0.165 \\
\hline No. of observations & 65 & 62 & 48 & 58 & 62 \\
\hline
\end{tabular}

Note: t-statistics in parentheses. ${ }^{* *},{ }^{*}$ denote significance at the 1 and 5 percent levels (two-tailed tests).

The next three figures present the non-linear relationship between globalisation and poverty graphically.

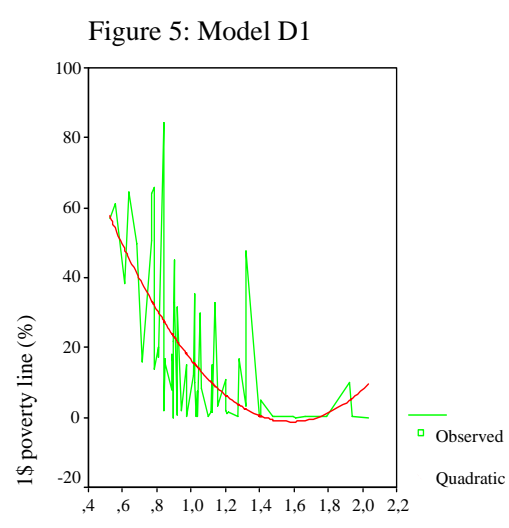

Globalisation Index

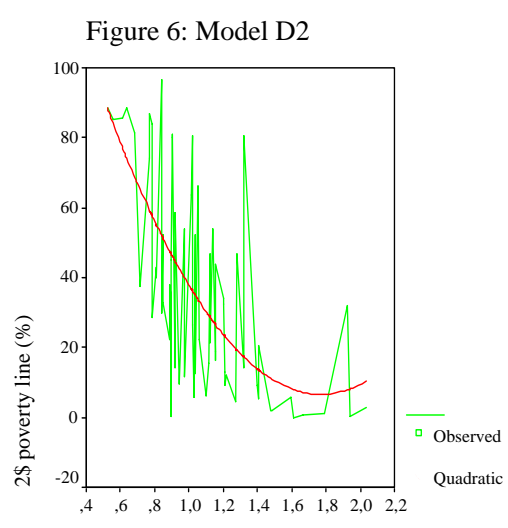

Globalisation Index

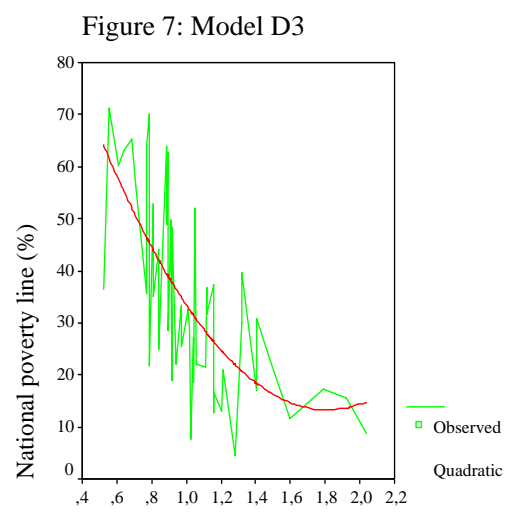

Globalisation Index 
These results are in contrast to all the results in the literature. Heshmati did not find a non-linear relationship, and Agénor determined an increase in poverty followed by a decrease in relation to economic integration. Here, the results show that there are diminishing returns to benefits from globalisation. This means that at low levels of globalisation further globalisation leads to poverty reduction. Once a country has moved up the globalisation index it will find that further globalisation still reduces poverty but at a slower pace. Further more the fit of the models is also much better than it is the case in the A models. In general for a robust non-linear relationship the small sample size and cross sectional data is less optimal.

In Model A1 we found an $\mathrm{R}^{2}$ of 0.320 , whereas in Model D1 the $\mathrm{R}^{2}$ increased to 0.455 . Model A2 had an $\mathrm{R}^{2}$ of 0.392 and increased in model D2 to 0.460 . Model A3 had an $\mathrm{R}^{2}$ of 0.410 and in model D3 this increased to 0.474 . When taking a closer look at the figures we see in all of the graphs, at the right tail of the regression line, a small disturbance. In Figure 5 and 6 this due to the high position of Malaysia on the globalisation index but with a rather high poverty level. In Figure 7 it is caused by Hungary and Malaysia due to similar reasons. Therefore, the fact that globalisation at high levels seems to worsen poverty is caused in the first two cases by Malaysia and the third case by Malaysia and Hungary.

\section{CONCLUSIONS}

This research tries to give some new insight into the relationship between globalisation, poverty and income inequality. In the literature, globalisation is mostly defined as an economic concept. Studies trying to relate globalisation, measured in terms of economic openness, financial integration and trade policies, to poverty and income inequality, show various results. Some studies 'prove' that globalisation helps the poor whereas others claim the opposite. So far, there is only one study on the discussion of poverty and globalisation that defines globalisation more widely than just economic interaction between countries. This is a study written by Heshmati (2006). He makes use of a globalisation index that is developed by A.T. Kearney / Foreign Policy Magazine and relates this index to poverty and income inequality. The index is 
constructed by four sub-indices, namely economic integration, personal contacts, technological connections and political engagement. His results show, an insignificant negative relationship between globalisation and poverty.

One weakness of his study and those by Kearney are the insufficient coverage of indicators of globalisation. We argued that some of the sub-indices do not include enough components. For instance, the technological connections index includes only data relating to internet technology. The economic integration component includes trade, investment and financial flow data, but does not include policy aspect regarding economic openness. In this paper we made an attempt to ameliorate the data and previous analysis by Heshmati. The limitations on the sample size and the globalisation index have been ameliorated. The sample of developing countries increased compared to Heshmati, while industrialized OECD countries are excluded from our sample. Another difference is that the two studies differ by the period of study 1995-2000 in Heshmati versus around 2001 in current study. Furthermore, the globalisation index in this study has been extended. The same sub-indices have been used, but in some cases more indicators are added. The differences in the results might be attributed to country sample and time period differences between the two datasets.

The new economic integration index has an added component of the degree of economic freedom. The personal connections index is extended by including the number of internet users. The technological connections index is completely revised. This index contains components derived from the Technology Achievement Index from the Human Development Report. Based on the before mentioned components an entire new globalisation index has been constructed for a much larger set of countries than the Kearney globalisation index. We also showed that the new globalisation index contains more information than economic globalisation, which has been the most common measure of globalisation in the literature so far.

We find that Estonia is the most globalised developing country followed by the Czech Republic and Malaysia. The least globalised countries are Burundi, Madagascar and Rwanda. When globalisation is related to GDP per Capita we showed that there is a positive relationship. No relationship has been established between globalisation and the size of a country measured in terms of population. 
When globalisation is related to geographical regions, we showed that there are differences in level of globalisation between the regions. The interregional spread is also rather large, indicating that the between geographical regions do not fully determine the effect of globalisation.

Various poverty and income inequality measures are used to see how they relate to globalisation. Poverty is measured in 3 ways, namely, the percentage of the population living below one dollar a day and two dollars a day, and the percentage of the population living below the national poverty level. Income inequality is measured by the Kuznets ratio and the Gini coefficient. Globalisation and the poverty and income inequality measures are first analysed through linear regression. The results show that high levels of globalisation relate to low levels of poverty, suggesting that globalisation improves the situation of the poor in developing countries. The results also show that globalisation reduces income inequality.

By having tested globalisation with different poverty and income inequality measures, we see that there are no differences when poverty is defined in relative or absolute terms. This shows that the argument often used, that poverty might be reduced by globalisation but income inequality worsens, has been proven wrong. These findings are in line with the results from Dollar. He showed that income inequality has slightly declined among globalisers and that globalisation is a positive force for poverty reduction. When controlling for regional heterogeneity we see that the relationship between globalisation and poverty remains significant. When globalisation is related to income inequality the globalisation coefficient becomes insignificant, showing that income inequality is than explained by unobserved regional heterogeneity and no longer by globalisation.

Finally, the relationship is tested for non-linearity. We showed that for poverty there are diminishing returns to benefits from globalisation. At low levels of globalisation further globalisation leads to poverty reduction. Once a country has moved up the globalisation index it will find that further globalisation still reduces poverty but at a slower pace. We found no quadratic relationship between globalisation and income inequality. These findings are in contrast to the findings from Agénor. The main reason causing the difference is probably the small sample size Agénor used. In his study he covered only 30 developing countries, which makes his study rather weak. Another 
reason is that his definition of trade openness is only focussed on tariffs and excludes trade data.

Although this study has extended the globalisation index and found a significant relationship between globalisation, poverty and income inequality there are some limitations.

First of all the data availability has been cumbersome. The statistical analysis is all based on cross-sectional regression. For globalisation, the data has been collected for 2001. The poverty measurements however have data from different years. For some countries the data was not available and data is included from earlier years. Further more, it would be much better to make use of panel data, to see how globalisation and poverty behaves over time. However, as mentioned earlier, this is very unlikely that this will ever be possible, due to the lack of proper data. Further more, the extended index is not yet developed well enough to our liking. One could argue for further additions to the index such as cultural effects and movement of skilled labour between countries.

Finally, we put forward some tentative suggestions on the causal links between the measures of globalisation and poverty. So far, we have mainly looked at the statistical relationship between globalisation and poverty. But behind this are various causal mechanisms. The fact that economic integration relates to poverty is rather clear cut. Increase in trade and foreign direct investments, a reduction in tariffs and other trade policies result in an increase of economic activities. These factors lead to higher GDP per capita, resulting in a decrease in poverty when the poor are also benefiting from the increase in GDP per capita. From this study it appears that from the economic integration the poor benefit too. Similar mechanisms apply for technological advancement. When a country is able to make use of new technologies they may increase their labour productivity which is one of the cornerstones of economic growth. Further more, when thinking in non-economic terms, access to technology may help the poor to have access to modern medicine and public health. Furthermore, access to ICT can be beneficial to the poor as it enables them to improve their educational standards and employment and business opportunities, which would otherwise be unavailable. The measures in this study indicate the level of technology gained from globalisation.

The third sub-index is personal contacts. This index indicates the globalisation level of the inhabitants of a country. The relation to poverty can be found in for instance 
the cross-border transfers. These transfers indicate the possibility for people to earn money abroad and send the money back into the economy. It is not uncommon that this type of money transfer is flowing back to the poor. Further more, in many developing countries tourism is an important source of income, of which the poor may benefit too. To some extent the international tourism sector is measured in the index as well, as well as the ability for inhabitants to travel abroad themselves.

The final sub-index is the political engagement. This measure indicates the level of integration on a political level with the rest of the world. This index is probably the least direct relating to poverty. But we believe there is certainly a connection. The three measures used are showing the level of international involvement of a country. The involvement is often relating to UN organisations and agreements, which are promoting the reduction of poverty. The link to poverty can be found in a deeper political determinant, which is good governance. Countries which are open to UN agreements and organisations as well as good connections with the developed world may reduce or at least strive for poverty reduction. Thus, our study covers a large spectrum of mechanisms through which globalisation can affect poverty 


\section{REFERENCES}

Agénor, Pierre-Richard (2003), “Does Globalization Hurt the Poor?”, World Bank Policy Research Working Paper 2003:2922.

Bhagwati, J., Srinivasan, T.N. (2001), “Trade and Poverty in the Poor Countries”, http://www.econ.yale.edu/ srinivas/trade_poverty.pdf

Central Intelligence Agency (2001), "World Fact Book 2001”, http://www.outfo.org/almanac/world_factbook_01

Dollar D. \& Collier P. (1999), “Aid allocation and poverty reduction”, World Bank Policy Research Working Paper 1999:2041.

Dollar D. \& Kraay A. (2001), “Trade, growth and poverty” World Bank Policy Research Working Paper 2001:2615

Europa World Fact Book 2001 (2001), Volume 1 and volume 2, Europa Publications Limited, Unwin Brothers Limited.

Heshmati A. (2006), “Measurement of a Multidimensional Index of Globalization”, Global Economy Journal 6(2), 1-30

Heshmati, A. (2004a), “The Relationship between Income Inequality, Poverty and Globalization”, IZA Discussion Paper 2004:1277.

Heshmati A. (2004b), "Data Issues and Databases used in Analysis of Growth, Poverty and Economic Inequality”, IZA Discussion Paper 2004:1263.

International Monetary Fund, International Statistics Browser, http://imfstatistics.org

Kearney A.T., Inc. (2002), “Globalization’s Last Hurrah?”, Foreign Policy, January/February 2002, http//:www.foreignpolicy.com

Kearney A.T., Inc. (2003), “Measuring Globalization: Who’s Up, Who’s Down?”, Foreign Policy, January/February 2003, http//:www.foreignpolicy.com

Kraay, A., Zoido-Lobatón, P., Kaufmann, D. (1999), “Governance Matters”, World Bank Policy Research Working Paper 1999:2496.

Miles M.A, Feulner E.J. \& Anastasia O’Grady M. (2005), “2005 Index of economic freedom”, The Hertiage Foundation, The Wall Street Journal.

Milanovic, B. (2002), “True world income distribution, 1988 and 1993: First calculation based on household surveys alone”, Economic Journal 112(476), 51-92.

Prasad E., Rogoff K., Wei, S.J. and Ayhan Kose, M. (2003), "Effects of Financial Globalization on Developing Countries: Some Empirical Evidence”, IMF. 
Ravaillion, M. (2003), “The debate on globalization, poverty and inequality: why measurement matters”, International Affairs 79(4), 739-735.

Ray, D. (1998), “Development Economics” Princeton University Press.

United Nations, data on peace keeping missions, http://www.un.org/Depts/dpko/dpko/home.shtml

Wade, R.H. (2004), “Is globalization reducing poverty and inequality?”, World Development Report 2004.

Watkins, K. (2002), “Making Globalization Working for the Poor”, Finance and Development 39(1), 000-000.

World Bank, “Globalization, Growth, and Poverty”, World Bank Policy Research Report, 2002

World Bank (2005), “World Development Indicators Online”.

World Bank Poverty Calculator, http://www.worldbank.org/lsms/tools/povcal

World Resource Institute, "Earth Trends: Environmental Information" http://www.earthtrends.wri.org

World Tourism Organization (2001), “Compendium of Tourism Statistics”.

United Nations Development Group (2003), “Indicators for Monitoring the Millennium Development Goals: Definitions, Rationale, Concepts and Sources”, United Nations. 


\section{APPENDIX A}

The first relationship between economic integration and personal contacts is shown in Figure 8. We see that there is a positive relationship; the higher the economic integration, the higher the level of personal contacts. With an $\mathrm{R}^{2}$ of 0.28 we see that personal contacts do add additional information to economic integration. We can therefore say that it is valid that personal contacts are added to the definition and quantification of globalisation.

Figure 8: Economic Integration and Personal Contacts

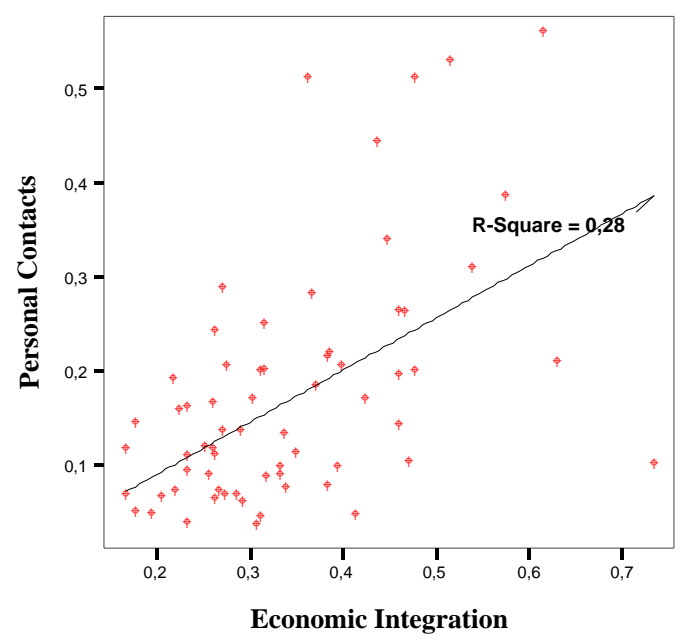

The same applies for technological connections (Figure 9). The relationship is positive but with quite considerable deviation. With an $\mathrm{R}^{2}$ of 0.2 , the technology index also gives additional information to economic integration and is therefore accepted in the globalisation index. 
Figure 9: Economic Integration and Technological Connections

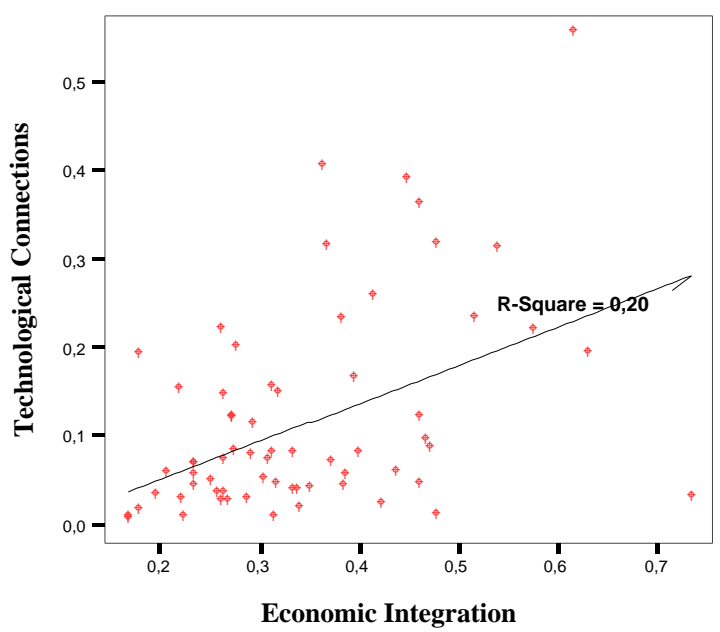

The final sub-index is the political engagement index. From Figure 11 we can conclude that the relationship is less apparent than the others. However, a negative relationship can be determined between the two indices. Once again, the spread is rather large and with an $\mathrm{R}^{2}$ of 0.02 this index is also an addition to the economic integration index.

Figure 11: Economic Integration and Political Engagement

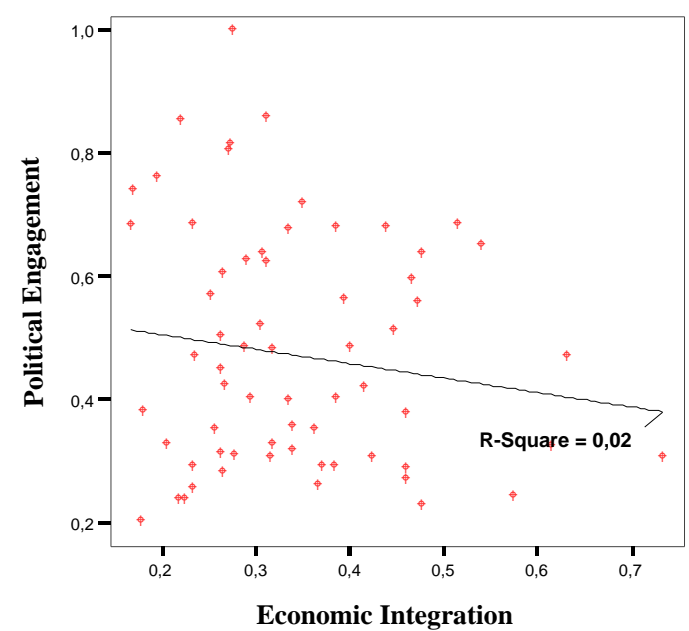

The last analysis of economic integration with the globalisation index (Figure 12) is to show that the globalisation index does give additional information to the economic integration index. The relationship is positive and shows quite some spread. 
With an $\mathrm{R}^{2}$ of 0.40 we show that additional indices for measuring globalisation, in terms of economic integration, do supply additional information. This extended definition of globalisation is now ready to be tested in relation to poverty.

Figure 12: Economic Integration and Globalisation Index

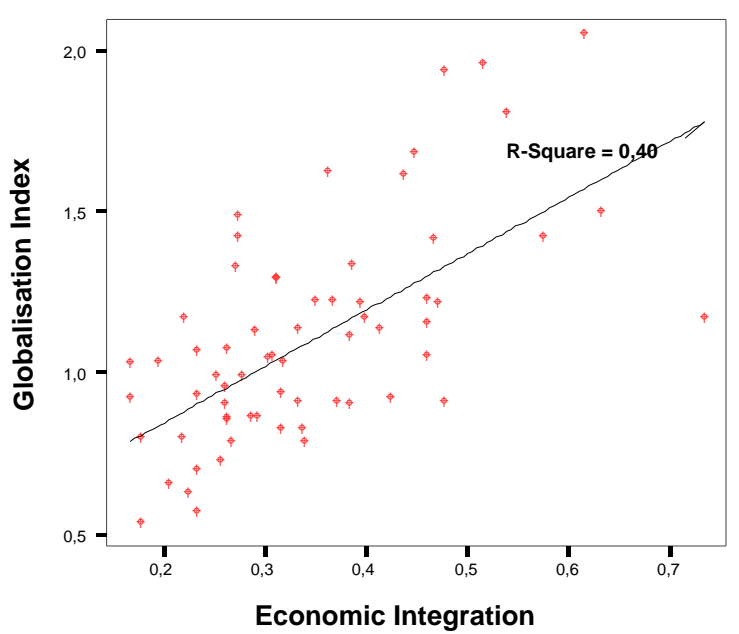

\section{APPENDIX B}

Table 8: Correlations table

\begin{tabular}{|c|c|c|c|c|c|c|c|c|c|c|}
\hline Variables & $\mathrm{N}$ & $1 \$$ & $2 \$$ & Nat pov & Kuznets & Gini & EI & PC & TC & $\mathrm{PE}$ \\
\hline $1 \$$ & 65 & & & & & & & & & \\
\hline $2 \$$ & 65 & $\begin{array}{l}.914^{* *} \\
(.000)\end{array}$ & & & & & & & & \\
\hline Nat pov. & 52 & $\begin{array}{l}.692 * * \\
(.000)\end{array}$ & $\begin{array}{l}.664^{* *} \\
(.000) \\
\end{array}$ & & & & & & & \\
\hline Share & 61 & $\begin{array}{l}-.279 * \\
(.030)\end{array}$ & $\begin{array}{l}-.208 \\
(.107)\end{array}$ & $\begin{array}{l}-.364^{*} \\
(0.11)\end{array}$ & & & & & & \\
\hline Gini & 63 & $\begin{array}{l}.330 * * \\
(.008)\end{array}$ & $\begin{array}{l}.284^{*} \\
(.024)\end{array}$ & $\begin{array}{l}.386^{* *} \\
(.006)\end{array}$ & $\begin{array}{l}.914^{* *} \\
(.000)\end{array}$ & & & & & \\
\hline EI & 65 & $\begin{array}{l}.384^{* *} \\
(.002)\end{array}$ & $\begin{array}{l}.502^{* *} \\
(.000)\end{array}$ & $\begin{array}{l}-.318^{*} \\
(.023)\end{array}$ & $\begin{array}{l}-.025 \\
(.851)\end{array}$ & $\begin{array}{l}-.008 \\
(.950)\end{array}$ & & & & \\
\hline PC & 65 & $\begin{array}{l}.277^{*} \\
(.025)\end{array}$ & $\begin{array}{l}-.488^{* *} \\
(.000)\end{array}$ & $\begin{array}{l}.355^{*} \\
(.011) \\
\end{array}$ & $\begin{array}{l}.277^{*} \\
(.031) \\
\end{array}$ & $\begin{array}{l}-.296^{*} \\
(.018) \\
\end{array}$ & $\begin{array}{l}.529 * * \\
(.000)\end{array}$ & & & \\
\hline TC & 65 & $\begin{array}{l}-.384 * * \\
(.002) \\
\end{array}$ & $\begin{array}{l}-.514 * * \\
(.000) \\
\end{array}$ & $\begin{array}{l}-.400 * * \\
(.004)\end{array}$ & $\begin{array}{l}.234 \\
(.070) \\
\end{array}$ & $\begin{array}{l}-.284^{*} \\
(.024) \\
\end{array}$ & $\begin{array}{l}.451^{* *} \\
(.000) \\
\end{array}$ & $\begin{array}{l}.624^{* *} \\
(.000) \\
\end{array}$ & & \\
\hline $\mathrm{PE}$ & 65 & $\begin{array}{l}-.327 * * \\
(.008) \\
\end{array}$ & $\begin{array}{l}.168 \\
(.182) \\
\end{array}$ & $\begin{array}{l}-.434 * * \\
(.001) \\
\end{array}$ & $\begin{array}{l}.422 * * \\
(.001)\end{array}$ & $\begin{array}{l}-.321 * \\
(.010)\end{array}$ & $\begin{array}{l}-.146 \\
(.245) \\
\end{array}$ & $\begin{array}{l}-.094 \\
(.458) \\
\end{array}$ & $\begin{array}{l}-.119 \\
(.347)\end{array}$ & \\
\hline GI & 65 & $\begin{array}{l}-.566^{* *} \\
(.000)\end{array}$ & $\begin{array}{l}-.626^{* *} \\
(.000)\end{array}$ & $\begin{array}{l}-.640^{* *} \\
(.000)\end{array}$ & $\begin{array}{l}.418^{* *} \\
(.001)\end{array}$ & $\begin{array}{l}-.404^{* *} \\
(.001)\end{array}$ & $\begin{array}{l}.632 * * \\
(.000)\end{array}$ & $\begin{array}{l}.731^{* *} \\
(.000)\end{array}$ & $\begin{array}{l}.677^{* *} \\
(.000)\end{array}$ & $\begin{array}{l}.450 * \\
(.000)\end{array}$ \\
\hline
\end{tabular}

Notes: t-statistics in parentheses. ${ }^{* *},{ }^{*}$ denote significance at the 1 and 5 percent levels (two-tailed tests). $1 \$ / 2 \$=$ percentage living below $1 / 2$ dollar(s) a day, Nat pov= percentage below national poverty line, Share= percentage of 20 percent with lowest national income or consumption, Gini= Gini coefficient, EI= economic integration, $\mathrm{PC}=$ personal contacts, $\mathrm{TC}=$ technological connections, $\mathrm{PE}=$ Political engagement, GI= globalisation index. 